
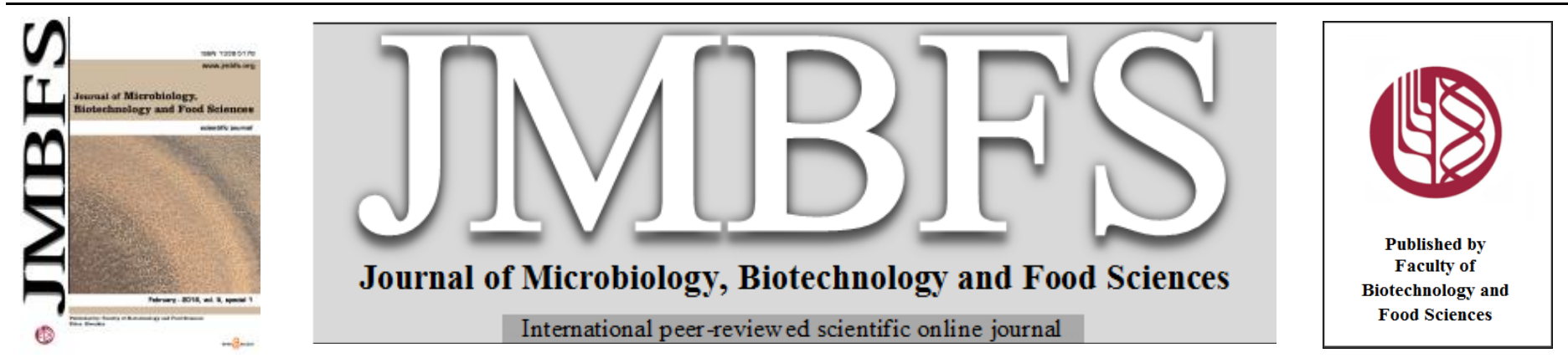

\title{
IN VITRO EFFECT OF 4-NONYLPHENOL ON CAMP STIMULATED ANDROSTENEDIONE PRODUCTION AND VIABILITY OF MICE LEYDIG CELLS
}

\author{
Tomáš Jambor*, Jana Lukáčovál ${ }^{1}$ Eva Tvrdál ${ }^{1}$ Zsolt Forgács ${ }^{2}$, Norbert Lukáč ${ }^{1}$
}

Address(es): MSc. Tomáš Jambor,

${ }^{1}$ Slovak University of Agriculture, Faculty of Biotechnology and Food Sciences, Department of Animal Physiology, Trieda A. Hlinku 2, 94976 Nitra, Slovak Republic, phone number: +421-37-6414288.

${ }^{2}$ National Institute of Chemical Safety, Nagyváradtér 2, H-1450, Budapest', Hungary, phone number: 06-1-476-1180.

*Corresponding author: tomasjambor1@ gmail.com

doi: 10.15414/jmbfs.2016.5.special1.14-16

ARTICLE INFO

Received 23. 12. 2015

Revised 22. 1. 2016

Accepted 27. 1. 2016

Published 8. 2. 2016

Regular article OPEN $\partial_{\text {ACCESS }}$

\begin{abstract}
The toxic effect of various environmental contaminants such as heavy metals or industrial chemicals such as alkylphenolson male reproductive systemwasfound. 4-nonylphenol (4-NP), one of the environmental contaminants used in the manufacture of plastics and other products, is released largely into the environment. The majority of studies on NP have focused on their endocrine disrupting and potential adverse effects on reproductive system. The target of our in vitro study was to determine the potential impact of 4-nonylphenol as an endocrine disruptor on the hormonal secretion and viability of mice Leydig cells. Cells were cultured with addition of $0.04 ; 0.2$; 1.0; 2.5; and $5.0 \mu \mathrm{g} / \mathrm{mL}$ of 4-nonylphenol for $44 \mathrm{~h}$ and compared with the control. Cells destined for the determination of androstenedione production were cultured in the presence of cyclic AMP solution. Quantification of cAMP stimulated androstenedion production directly from aliquots of the medium was performed by enzyme linked immunosorbent assay (ELISA). The viability of Leydig cells was detected by the metabolic activity (MTT) assay. The cAMP stimulated androstenedione production significantly $(P<0.05)$ decreased at 2.5 and $5.0 \mu \mathrm{g} / \mathrm{mL}$ of 4-nonylphenol concentration. The viability of mice Leydig cells was decreased at the doses of $0.2 ; 1.0 ; 2.5$ and $5.0 \mu \mathrm{g} / \mathrm{mL}$ of 4-nonylphenol, but this decrease was not significant. Further investigations are essential to clarify the mechanism of action of endocrine disruptor on male mice, as well as to establish the biological significance of the observed phenomena.
\end{abstract}

Keywords: Leydig cells, nonylphenol, androstenedione, viability

\section{INTRODUCTION}

In present is increasing evidence that various chemicals such as pesticides, heavy metals and endocrine disrupters, introduced into the environment have the potential to damage endocrine system in wildlife and humans. The endocrine disrupting chemicals (EDCs) are an exogenous substances or mixture that alters functions of the endocrine system and consequently causes adverse health effects in an intact organisms (Sanderson, 2006). These chemicals interfere with the synthesis, metabolism or action of hormones. The list of chemical compound affecting the action of sex hormones is growing. EDCs are able to mimic, block or modulate natural hormones and other chemical messengers. In addition the important effect of EDCs is in change in the ratio of estrogen to testosterone (either directly, through an increase in levels of estrogen mimics, or indirectly through metabolic changes resulting in changed $17 \beta$-estradiol levels). This ratio is crucial for normal sexual development. Besides continuous impact of EDCs increase the risk of development of certain cancers (Nimrod and Benson, 1996). Alkylphenolsethoxylate (APEO) are potential endocrine disrupting chemicals This group consists of approximately $80 \%$ nonylphenolethoxylate (NPEO). NPEO are highly cost effective surfactants with exceptional performance and consequently used widely in industrial, commercial and household applications. The primary degradation product of NPEO is nonylphenol (NP). The term nonylphenol represents a large number of isomeric compounds varying in the point of attachment of the nonyl group to the phenol molecule and in the degree of branching in the nonyl moiety. It is common environmental contaminant widely used as part of detergents, paints and many other synthetic products. With development of industry, large amounts of nonylphenol were discharged into water, nature and environment (Wang and Shen, 1999). Many studies have classified NP as hazardous to the health of human and animals, especially to male reproduction. This metabolite has a structure mimicking estradiol and has been reported to have xenoestrogenic effects. NP exposure inhibits the growth of testes, affects the production and survival of sperms and also may cause significantly on hormone concentration (Blomet al., 1998; Han et al., 2004, Junk et al., 1974). Somatic testicular Leydig cells (LC) are an important part development of male reproductive organs and male reproduction. Moreover, LC are the primary and the main place of hormone biosynthesis. These cells are located in the testicular interstitium, between seminiferous tubules. They have spherical shape and contain a lot of amounts smooth endoplasmic reticulum and mitochondria. In the mice are classified two generations of Leydig cells namely fetalLeydig cells and adult Leydig cells. FetalLeydig cells start to appear in the mesenchyme of the developing in prenatal testis at 14.5 weeks. Adult type of Leydig cells originate within the mice testis by day about 56. postnatally. Their formation is the product of active proliferation and differentiation of undifferentiated stem cells. Despite their differences in biochemical and morphological parameters, fetal and adult Leydig cells share the same principal function to produce androgens (Steinberger and Fischer, 1969).

The level of testosterone and other sex hormones are responsible for the maintenance of spermatogenesis and secondary sexual characteristics in the male. We have to emphasize thought that NP affect important mechanism called steroidogenesis. The mechanism by which nonylphenol modulates this process has not been well defined, but it can be partially explained by the inhibition or activation of the key enzymes required for the biosynthesis of hormones in Leydig cells, including CYP11A, 3 $\beta$-HSD or 17 $\beta$-HSD (Laurenza et al., 2002; Payne and Sha, 1991). In addition, NP administration increased reactive oxygen species (ROS) level and depressed the activity of antioxidant enzymes in testis. Higher level of ROS may initiate a series of reactions that damage cellular components resulting in cell death. Moreover, nonylphenol has been identified that can bind to the estrogen receptor and initiate transcription of the estrogen receptor - regulated genes in vitro (Bolger et al., 1998; Danzo, 1997; Gould $\boldsymbol{e}$ al., 1998). Although a lot of chemicals has the potential to disrupt reproductive function, their actual impact on reproductive health has not been defined thoroughly. The present study was conducted to evaluate the possible effect of 4 nonylphenol at different concentrations on cAMP stimulated androstenedione production and viability in mice Leydig cells.

\section{MATERIAL AND METHODS}

Mice Leydig cells can be isolated without enzyme treatment or by trypsinization (Bilinska and Stoklosowa, 1977). In our in vitro study interstitial cells were 
isolated by mechanical dissociation without enzyme treatment as previously described by Stoklosowa (1982) with slight modification. NMRI mice (Institute of Experimental Pharmacology, Slovak Academy of Sciences, Dobra Voda Slovak Republic), 30-40g of weight and 8-9 week old were kept in a room and maintained on a $12 \mathrm{~h}$ light:dark cycle and $20-25^{\circ} \mathrm{C}$. In brief, twenty-six decapsulated testicles were placed on a grid or a sieve (of about $300 \mu \mathrm{m}$ opening size) over a beaker. All next steps were performed under sterile conditions. With the help of a $10 \mathrm{~mL}$ syringe and needle (Luer 22G), interstitial cells were rinsed out with a vigorous stream of minimum essential medium (MEM, Live Technologies, Bratislava, Slovak Republic) without serum to beaker placed on ice. The cell suspension was subsequently collected and centrifuged. After centrifugation $\left(300 \mathrm{x} \mathrm{g}\right.$, for $\left.10 \mathrm{~min}, 4^{\circ} \mathrm{C}\right)$ the cells were washed twice and resuspended. Subsequently the cell suspension was adjusted with culture medium (MEM) supplemented with 10\% fetal bovine serum (FBS; BiochromAG, Berlin, Germany), $100 \mathrm{IU} / \mathrm{mL}$ penicillin and $100 \mu \mathrm{g} / \mathrm{mL}$ streptomycin (Sigma - Aldrich, Bratislava, Slovak Republic) to a final concentration of $10^{6}$ cells $/ \mathrm{mL}$. The cells were plated into sterile 24-well plates (Nunclon, Denmark). Then were treated for 44h in MEM medium that contained various concentration of 4-nonylphenol (4$\mathrm{n}-\mathrm{NP}$; Fluka, Buchs, Switzerland), 0.04; $0.2 ; 1.0 ; 2.5$ and $5.0 \mu \mathrm{g} / \mathrm{mL}$. Cells destined for the determination of androstenedione production were cultured in the presence of cyclic AMP solution (db-cAMP, Sigma - Aldrich, Bratislava, Slovak Republic). All incubations were carried out at $34^{\circ} \mathrm{C}$ under a humidified atmosphere of $95 \%$ air and $5 \% \mathrm{CO}_{2}$. After cell treatment the media were removed and frozen at $-20^{\circ} \mathrm{C}$ until androstenedione determination. The resulting cell suspension was used for cell viability assessment.

\section{Quantification of cAMP-stimulated androstenedione production}

Determination of the androstenedione directly from aliquots of the culture media was performed by enzyme linked immunosorbent assay (ELISA). The ELISA kits were purchased from Dialab (androstenedione Cat. \# K00197, Austria). These kits were used for quantitative determination steroid hormones and the samples were measured at wavelength $450 \mathrm{~nm}$.

\section{Cytotoxicity evaluation}

The viability of the cells exposed to 4-nonylphenol in vitro was evaluated by the metabolic activity (MTT) assay (Mosmann et al., 1983). This colorimetric assay measures the conversion of a yellow water-soluble tetrazolium salt $(3-(4,5-$ dimetylthiazol - 2-yl)-2, 5 - diphenyl tetrazolium bromide) to purple formazan particles by mitochondrial succinate dehydrogenase of intact mitochondria of living cells. The amount of formazan was measured spectrophotometrically. In brief, interstitial cells were stained with a tetrazolium salt - MTT (Sigma, St. Louis, USA) and 24-well plates were inserted into a $\mathrm{CO}_{2}$ incubator. After $3 \mathrm{~h}$ of incubation $\left(34^{\circ} \mathrm{C}\right.$, humidified atmosphere of $95 \%$ air and $\left.5 \% \mathrm{CO}_{2}\right)$ the reaction was stopped with $1 \mathrm{~mL} /$ well of isopropanol (2-propanol, p. a. CentralChem, Bratislava, Slovak Republic). The optical density was determined at a measuring wavelength of $570-620 \mathrm{~nm}$ by an ELISA reader (Multiscan FC, ThermoFisher Scientific, Vantaa, Finland). The data were expressed in percentage of control.

\section{Statistical Analysis}

Obtained data were statistically analyzed using PC program GraphPad Prism 3.02 (GraphPad Software Incorporated, San Diego, California, USA). One way analysis of variance (ANOVA) and the Dunnett's multiple comparison test were used for statistical evaluations. The level of significance was set at *** $(P<0.001)$ $* *(P<0.01)$ and * $(P<0.05)$.

\section{RESULTS AND DISCUSSION}

In our in vitro study, Leydig cells were exposed to various concentrations of 4 nonylphenol $(0.04 ; 0.2 ; 1.0 ; 2.5$ and $5.0 \mu \mathrm{g} / \mathrm{mL})$ for $44 \mathrm{~h}$. Different doses of this endocrine disruptor showed a possible effect on cAMP stimulated androstenedione production. As seen in Figure 1, the androstenedione production was significantly $(P<0.05)$ decreased at the $2.5 \mu \mathrm{g} / \mathrm{mL}$ concentration of 4 nonylphenol. CAMP stimulated hormone production also significantly $(P<0.001)$ decreased at the highest doses $(5.0 \mu \mathrm{g} / \mathrm{mL})$ of 4-nonylphenol in comparison with CTRL group (without 4-NP treatment). Results of study indicated dose dependent decreases in cAMP androstenedione production of Leydig cells following a 44h in vitro 4-nonylphenol exposure.
The effect of 4-nonylphenol on the cAMP stimulated androstenedione production in mice Leydig cells



4-nonylphenol $[\mu \mathrm{g} / \mathrm{mL}]$

Figure 1 The effects of 4-nonylphenol on the cAMP stimulated androstenedione production after $44 \mathrm{~h}$ of in vitro cultivation.

Legend: Ctrl - control group. Each bar represents the mean $( \pm \mathrm{SEM})$ androstenedione \% of control (untreated) and treated group. The level of significance was set at $* * *(P<0.001) * *$ $(P<0.01)$ and $*(P<0.05)$

The viability of mice Leydig cells was detected by the MTT cytotoxicity assay. The MTT assay measures the reduction of MTT to blue formazan in viable cells. Figure 2 shows potential impact of 4-NP on the Leydig cell viability after a $44 \mathrm{~h}$ of in vitro cultivation. Viability of Leydig cells was slightly decreased at the lowest doses of 4-nonylphenol $(0.04$ and $0.2 \mu \mathrm{g} / \mathrm{mL})$. Lower cell viability was recorded in the experimental groups supplemented with 2.5 and $5.0 \mu \mathrm{g} / \mathrm{mL}$. However, this decrease was not significant in comparison with CTRL group (without 4-NP treatment). The results of this study suggested that lower concentration of 4 - nonylphenol do not damage the mitochondrial activity of mice Leydig cells.

The effect of 4-NP on cAMP stimulated viability in mice Leydig cells

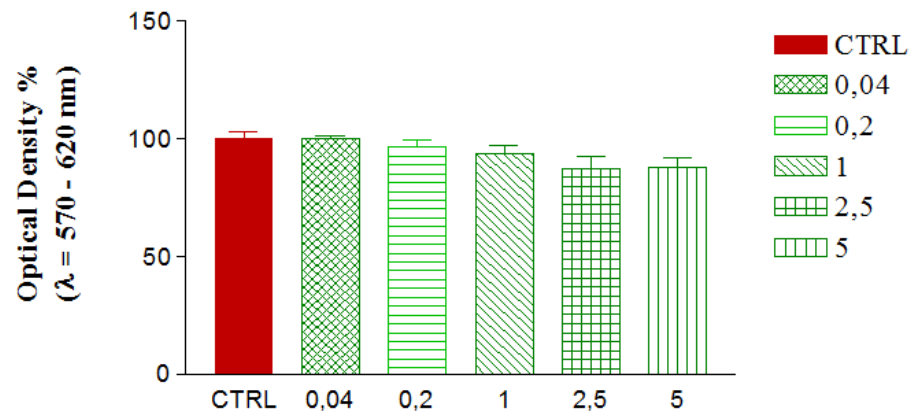

4-nonylphenol $[\mu \mathrm{g} / \mathrm{mL}]$

Figure 2 The effects of 4-nonylphenol on the cAMP stimulated Leydig cells viability after $44 \mathrm{~h}$ of in vitro cultivation.

Legend: Ctrl - control group. Each bar represents the mean ( \pm SEM) viability \% of control (untreated) and treated group. The level of significance wa set at $* * *(P<0.001) * *(P<0.01)$ and $*(P<0.05)$

Various chemicals found in the human and wildlife environments have the potential to disrupt endocrine functions in exposed organisms. A lot of in vivo and in vitro experiments on 4-nonylphenol have focused on their endocrine disrupting and potential adverse effects on developing reproductive system (Sanderson, 2006). Previous studies were usually performed using commercial nonylphenol, which is a mixture of many isomers. Kim et al. (2004) demonstrated that nonylphenol isomers had differential effects on the release of hormones in Leydig cells. The results of our study indicate dose-dependent decrease in cAMP stimulated androstenedione production of Leydig cells following in vitro 4-nonylphenol treatment after $44 \mathrm{~h}$ of cultivation. Androstenedione production was significantly $(P<0.05)$ decreased at the 2.5 $\mu \mathrm{g} / \mathrm{mL}$ of 4-nonylphenol. Higher dose $(5.0 \mu \mathrm{g} / \mathrm{mL})$ of 4-nonylphenol also significantly $(P<0.001)$ decreased hormonal production. Diemer et al. (2003) stimulated the MA-10 cell line using 8-Br-cAMP. In addition, the experimental groups were treated with $\mathrm{H}_{2} \mathrm{O}_{2}$. The result pointed out a decrease in the progesterone production when applying 100, 250 and $500 \mu \mathrm{M} \mathrm{H}_{2} \mathrm{O}_{2}$ in comparison with cells treated with cAMP alone.

In the other in vitro study, MA -10 cells were treated with different doses of mono-(2-etylhexyl) phthalate (MEHP) for $24 \mathrm{~h}$ and then maximally stimulated by luteinizing hormone $(\mathrm{LH})$ for $2 \mathrm{~h}$. The ability of the cells to produce cAMP 
(essential for steroidogenesis) in response to LH was reduced significantly by exposing the cells to increasing MEHP concentrations. Consequently, it was observed dose-dependent reductions in cAMP stimulated progesterone production without effect on the ability of the cells to reduce MTT. These results suggested that in addition to its effects on cAMP production, MEHP exposure might also affect downstream in the steroidogenic pathway (Zhou et al., 2013) We hypothesize that increased oxidative stress in response to 4-nonylphenol might be responsible for the reduced intracellular cAMP and androstenedione production.

Mitochondria are one of the most important organelle of cells. Mitochondria are also target of many toxic compounds since damage to mitochondria which synthesize ATP gives rise to corresponding cells damage (Higgins and Rogers, 1974; Bragadin et al., 1998). Bragadin et al. (1999) found out that a low level dose of nonylphenol inhibits ATP synthesis in mitochondria. Yao et al. (2007) investigated the effects of nonylphenol on the mitochondrial membrane potential and confirmed that the mitochondrial permeability transition was an important step in the induction of cellular apoptosis. In our in vitro study we found that different doses of 4-nonylphenol affected the Leydig cells viability after 44h of cultivation. Some concentration $(0.2 ; 1.0 ; 2.5$ and $5.0 \mu \mathrm{g} / \mathrm{mL})$ of 4 -nonylphenol reduce cells viability. On the other hand, significant decrease was not demonstrated. Wu et al. (2010) treated rat Leydig cells with different concentrations $(42.5 ; 127.5$ and $425.0 \mu \mathrm{M})$ of 4-nonylphenol. This highest dose exhibited a cytotoxic effect. Gong et al. (2009) examined the effect of nonylphenol $(0.1 ; 1.0 ; 10.0 ; 20.0$ and $30.0 \mu \mathrm{M})$ during time periods $6 \mathrm{~h}, 12 \mathrm{~h}$ and $24 \mathrm{~h}$ on viability of rat testicular Sertoli cells. In this case a significant decrease was reported after $24 \mathrm{~h}$ cultivation. Therefore the exposure to nonylphenol in animals and humans must be seriously observed.

\section{CONCLUSION}

Recent studies have hypothesized that environmental exposure to nonylphenol poses adverse effects on reproductive system of humans and wildlife species Therefore the exposure to nonylphenol and other endocrine disruptor in animals and humans must be seriously observed. Many authors investigated the toxic effect of nonylphenol on various types of cells. The data presented in our in vitro study describe the impact of endocrine disruptor on the Leydig cell biosynthesis of androstenedione and viability of cells after $44 \mathrm{~h}$ treatment. We may conclude that some experimental doses $(2.5$ and $5.0 \mu \mathrm{g} / \mathrm{mL})$ may significantly decrease cAMP stimulated androstenedione production, however in the case of cell viability an insignificant decrease was observed.

Acknowledgments: This study was supported by the European Community under the Project no. 26220220180: Building Research Centre „AgroBioTech" and the Scientific Grant Agency of the Ministry of Education of the Slovak Republic VEGA, Project no. 1/0857/14.

\section{REFERENCES}

BILINSKA, B., STOKLOSOWA, S. (1977). Activity of $\Delta^{5}, 3 \beta$-hydroxysteroid dehydrogenase in cultured interstitial cells of mouse testes.EndocrinologiaExperimentalis, 11, 169-174.

BLOM, A., EKMAN, E., JOHANNISSON, A., NORRGREN, L., PESONEN, M. (1998). Effects of xenoestrogenic environmental pollutants of the proliferation of a human breast cancer cell line (MCF-7). Archives of Environmental Contamination and Toxicology, 34(3), 306-310.

BOLGER, R., WIESE, T.E., ERVIN, K., NESTICH, S., CHECOVICH, W. (1998).Rapid screening of enrivonmental chemicals for estrogen receptor binding capacity.Environmental Health Perspectives, 106(3), 294-301. http://dx.doi.org/10.10007/s002449900322

BRAGADIN, M., MARTON, D., MURGIA, M., RIZZOLLI, V., SCUTARI, G., DEANA, R. (1998).Interactions of trialkyllead compounds with rat liver mitochondria.The Journal of Inorganic Biochemistry,69(4), 259-262. http://dx.doi.org/10.1016/s0162-0134(97)10036-8

BRAGADIN, M., PERIN, G., IERO, A., MANENTE, S., RIZZOLI, V., SCURAGRI, G. (1999).An in vitro study on the toxic effects of nonylphenols in mitochondria.Chemosphere, 38(9), 1997-2001. http://dx.doi.org/ 10.1016/s00456535(98)00412-3

DANZO, B.J. (1997). Environmental xenobiotics may disrupt normal endocrine function by interfering with the binding of physiological ligand to steroid receptors and binding proteins. Environmental Health Perspectives, 105(9), 551557. http://dx.doi.org/10.1289/ehp.97105294

DIEMER, T., ALLEN, J.A., HALES, H.K., HALES, D.B., (2003). Reactive oxygen disrupts mitochondria in MA-10 tumorLeydig cells and inhibits steroidogenic acute regulatory (StAR) protein and steroidogenesis Endocrinology, 144(7), 2882-2891.http://dx.doi.org/10.1210/en.2002-0090

GONG, Y., WU, J., HUANG, Y., SHEN, S., HAN, X.D. (2009).Nonylphenol induces apoptosis in rat testucularSertoli cells via endoplasmatic reticulum stress. Toxicology Letters, 186(2), 84-95. http://dx.doi.org/10.1016/j.toxlet.2009.01.010 GOULD, J.C., LEONARD, L.S., MANESS, S.C., WAGNER, B.L., CONNER K., ZACHAREWSKI, T., SAFE, S., McDONNELL, D.P., GAIDO, K.W. (1998)
Bisphenol A interacts with the estrogen receptor alpha in a distinct manner from estradiol. Molecular and Cellular Endocrinology, 142(1-2), 203-214. http://dx.doi.org/10.1016/s0303-7207(98)00084-7

HAN, X.D., TU, Y.Z., GONG, Y., SHEN, S.N., WANG, X.Y., KANG, L.N., HOU, Y.Y., CHEN,.J.X. (2004). The toxic effect of nonylphenol on the reproductive system of male rats.Reproductive Toxicology, 19(2), 215221.http://dx.doi.org/ 10.1016/i.reprotox.2004.06.014

HIGGINS, E.S., ROGERS, K.S. (1974). Effects of cetyltrimethylammonium and dodecylnicotinamide halides on functional states of mitochondria.Proceedings of the Society for Experimental Biology and Medicine, 146(1), 85-91. http://dx.doi.org/10.3182/00379727-146-38048

JUNK, G.A., SVEC, H.J., VICK, R.D., AVERY, M.J. (1974).Contamination of water by synthetic polymer tubes.Environmental Science and Technology, 8, 1100-1106.http://dx.doi.org/10.1021/es60098a009

KIM, Y.S., KATASE, T., SEKINE, S., INOUE, T., MAKINO, M., UCHIYAMA, T., FUJIMOTO, Y., YAMASHITA, N. (2004).Variation in estrogenic activity among fractions of a commercial nonylphenol by high performance liquid chromatography.Chemosphere, 54, 1127 1134.http://dx.doi.org/10.1016/j.chemosphere.2003.09.024

LAURENZA, E.M., BALASUBRAMANIAN, G., WEIS, C., BLAYDES, B., NEWBOLD, R.R., DELCLOS, K.B. (2002). Effect of nonylphenol on serum testosterone levels and testicular steroidogenic enzyme activity in neonatal, pubertal, and adult rats.Chemico-Biological interactions, 139(1), 23 41.http://dx.doi.org/10.1016/s0009-2797(01)00291-5

MOSMANN, T. (1983). Rapid colorimetric assay for cellular growth and surrival: application to proliferation and cytotoxicity assays. Journal of Immunological Methods, 65(1), 55-63. http://dx.doi.org/10.1016/00221759(83)90303-4

NIMROD, A.C., BENSON, W.H. (1996). Environmental estrogenic effects of alkylphenoletoxylates.Critical Reviews in Toxicology, 26, 335-364.

PAYNE, A.H., SHA, L. (1991). Multiple mechanisms for regulation of $3 \beta$ hydroxysteroiddehydogenase $/ \Delta^{5} \rightarrow \Delta^{4}$-Isomerase, $17 \alpha$-Hydroxylase/ $\mathrm{C}_{17-20}$ Lyase Cytochrome P450, and Cholesterol Side-Chain Cleavage Cytochrome P450 Messenger Ribonucleic Acid Levels in Primary Cultures of Mouse Leydig Cells. Endocrinology, 129(3), 1429-1435. http://dx.doi.org/10.1210/endo-129-3-1429

SANDERSON, T.J. (2006). The steroid hormone biosynthesis pathway as a target for endocrine disrupting chemicals.Toxicological sciences, 94(1), 321.http://dx.doi.org/10.1093/toxsci/kfl051

STEINBERGER, E., FISCHER, M. (1969).Differentiation of steroid biosynthetic pathways in developing testes.Biology of Reproduction, 1, 119133.http://dx.doi.org/ 10.1095/biolreprod1.supplement 1.119

STOKLOSOWA, S. (1982).Tissue culture of gonadal cells.ActaBiologicaAcademiaeScientiarumHungaricae, 33(4), 367-379.

WANG, H., SHEN, Y.W. (1999). Environmental estrogenic effects of alkylphenolethoxylates.China Environmental Science, 19(5), 472-431.

WU, J.J., WANG, K.L., WANG, S.W., HWANG, G.S., MAO, I.F., CHEN, M.L., WANG, P.S. (2010). Differential effects of nonylphenol on testosterone secretion in rat Leydig cells. Toxicology,268, 1-7. http://dx.doi.org/10.1016/j.tox.2009.10.030

YAO, G., LING, L., LUAN, J., YE, D., ZHU, P. (2007).Nonylphenol induces apoptosis of Jurkat cells by a caspase- 8 dependent mechanism. International

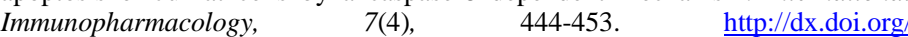
10.1016/j.intimp.2006.11.013

ZHOU, L., BEATTIE, M.C., LIN, I.CH., LIU, J., TRAORE, K. PAPADOPOULOS, V., ZIRKIN, B.R., CHEN, H. (2013) Oxidative stress and phthalate induced down regulation of steroidogenesis in MA-10 Leydig cells Reproductive Toxicology,42, 95-101. http://dx.doi.org/ $\underline{0.1016 / \text { j.reprotox.2013.07.025 }}$ 